\title{
Analysis of the use of venture capital in Central and Eastern Europe countries
}

\author{
Lenka Kalusová ${ }^{1, *}$ \\ ${ }^{1}$ University of Economics in Bratislava, Department of Business Finance, 85235 Bratislava, Slovakia
}

\begin{abstract}
We classify venture capital as a non-standard, alternative source of financing. Venture capital has an important position especially in financing innovative project activities. For this reason, the main goal of the paper is to analyze the use of venture capital in the countries of Central and Eastern Europe with the focus on the Visegrad Group countries. We used scientific methods, both from the general - logical methods, as well as from exact methods (in the form of statistical methods and comparison). We analysed the years $2010-2018$. The results of our study show that the use of venture capital is very low in the Central and Eastern Europe countries.
\end{abstract}

\section{Introduction}

Venture capital can be in terms of classification of funding sources included in the category of alternative sources. The authors Srpová and Řehoř [14] consider venture capital as capital that "participates in the financing of private growth companies by increasing their share capital. It is a partnership of the entrepreneur and the investor." Kleinschmidt [16] considers venture capital to be a type of capital used to finance the growth of private companies over a defined period, and according to his definition of venture capital, the provision of venture capital also includes the provision of non-financial support to the company. The author's definition includes four characteristic attributes of venture capital, which are equity financing, medium-term investments, a focus on growth companies and active investing. Based on the above definitions of venture capital, we can therefore conclude that risk capital is considered risky because it finances projects for which it is difficult to obtain funding because they are more risky than other projects.

The use of venture capital and the factors affecting venture capital are the subject of research by several academic. The authors Groh and Liechtenstien [2] analyzed determinants of venture capital allocation in CEE countries. The authors examined the impact of 6 main determinations. The research results point to the fact, that investors are satisfied with the economic potential and entrepreneurial opportunities, the problems in venture capital investments are caused mainly by the investor protection as well as the poor level of the depth of capital markets. The impact of the depth of the capital market in Poland on the use of venture capital was examined by Soloma [5]. The author found that although Poland is roughly equal in terms of the ratio of venture capital investments to

\footnotetext{
*Corresponding author: lenka.kalusova@euba.sk
} 
GDP to other Central and Eastern European countries, the author found that it is more attractive to investors than other countries, mainly due to the well-developed Warsaw Stock Exchange (about 40\% of all primary emissions in Europe was in 2012 in Warsaw The role of institutions supporting the development of venture capital in 18 European countries has been the subject of research by Bedu and Montalban [17]. The results of the study point to a strong correlation between the growth of the size of the capital market and the growth of venture capital investments, which is also confirmed by the previous findings of the author Soloma. The foundations emphasize the importance of country regards to development of venture capital investments. The use of venture capital as one of the possible alternatives to standard sources of funding in Romania is discussed in an article by Prelipean et al. [9]. Studies by several authors $[11,6,7]$ show that the financial crisis has had an impact on the use of venture capital. According to Block and Sanders [12], the financial crisis has caused a reduction in venture capital to finance businesses. Ning et al. [19] report that macroeconomic factors significantly affect the use of venture capital. Likewise, Gomes Santa Felix et al. [8] confirm that the level of venture capital utilization affects the environment in which businesses operate as well as the degree of asymmetric information. This is also confirmed by a study by Jeng and Wells [15], Groh and Liechtenstein [1] who noted that there are significant differences between the uses of venture capital across countries. Another study Groh and Wallmeroth [4] adds that there are different factors influencing the use of venture capital in developed and developing economies.

Based on the domestic and foreign literature search, the main goal of our contribution is to analyze, evaluate and appreciate venture capital funding in Central and Eastern Europe Countries.

\section{Methodology}

We obtained information for our research from both domestic and foreign literature. The main source of statistics on the use of risk capital in the Central and Eastern Europe Countries was the Central and Eastern Europe Statistics. We analyzed the years 2010 2018.

The processing of research requires the use of several scientific methods, both from the group of general - logical methods and from the group of exact methods (in the form of statistical methods and comparison). The method of comparison was used both in the theoretical part of the paper and in its application part. In the theoretical part, we compared the views of different authors on the use of venture capital. We also analyzed the views of various authors on the use of venture capital depending on the economic cycle. In the practical part, we compared the use of venture capital in the Central and Eastern Europe countries and Europe as a whole. At the same time, we also compared the use of venture capital in the Visegrad Group countries. The results of our research are presented in tables and figures.

\section{Results and discussion}

The use of venture capital varies from one European country to another. Table 1 shows the total amount of risk capital used in Europe and especially in the countries of Central and Eastern Europe. The table shows these data according to the specific forms of risk capital used. The year 2018 was subjected to analysis. 
Table 1. The value of venture capital investments according to particular types of venture capital in CEE countries and Europe (2018).

\begin{tabular}{|c|c|c|c|c|c|}
\hline \multirow{2}{*}{$\begin{array}{c}\text { Type of } \\
\text { investments }\end{array}$} & \multicolumn{2}{|c|}{$\begin{array}{c}\text { Value of investment in } \\
\text { CEE countries } \\
\text { Value of investment in } \\
\text { Europe }\end{array}$} & $\begin{array}{c}\text { CEE } \\
\text { countries' s } \\
\text { investments } \\
\text { ratio to } \\
\text { Europe as a } \\
\text { whole }\end{array}$ \\
\cline { 2 - 6 } & $\begin{array}{c}\text { EUR } \\
\text { Thousand }\end{array}$ & $\%$ & $\begin{array}{c}\text { EUR } \\
\text { Thousand }\end{array}$ & $\%$ & $\%$ \\
\hline Seed capital & 38097 & $1.42 \%$ & 721445 & $0.90 \%$ & $5.28 \%$ \\
\hline Start-up capital & 97786 & $3.64 \%$ & 4887307 & $6.07 \%$ & $2.00 \%$ \\
\hline Expansion capital & 638463 & $23.78 \%$ & 14481478 & $17.97 \%$ & $4.41 \%$ \\
\hline Rescue capital & - & - & 254799 & $0.32 \%$ & - \\
\hline Replacement capital & 24624 & $0.92 \%$ & 142016 & $0.18 \%$ & $17.34 \%$ \\
\hline $\begin{array}{c}\text { Management buy- } \\
\text { out - MBO }\end{array}$ & 1885972 & $70.24 \%$ & 58814426 & $72.99 \%$ & $3.21 \%$ \\
\hline Total 2018 & $\mathbf{2 6 8 4 9 4 3}$ & $\mathbf{1 0 0 . 0 0 \%}$ & $\mathbf{8 0 ~ 5 8 1 4 7 1}$ & $\mathbf{1 0 0 . 0 0 \%}$ & $\mathbf{3 . 3 3 \%}$ \\
\hline Total 2017 & 3532018 & - & 75324705 & - & $4.69 \%$ \\
\hline
\end{tabular}

In table 1 we can clearly see that the ratio of venture capital investment in the Central and Eastern Europe countries to the total volume within Europe is only 3.33\% in 2018 (the previous year $4.69 \%$ ).

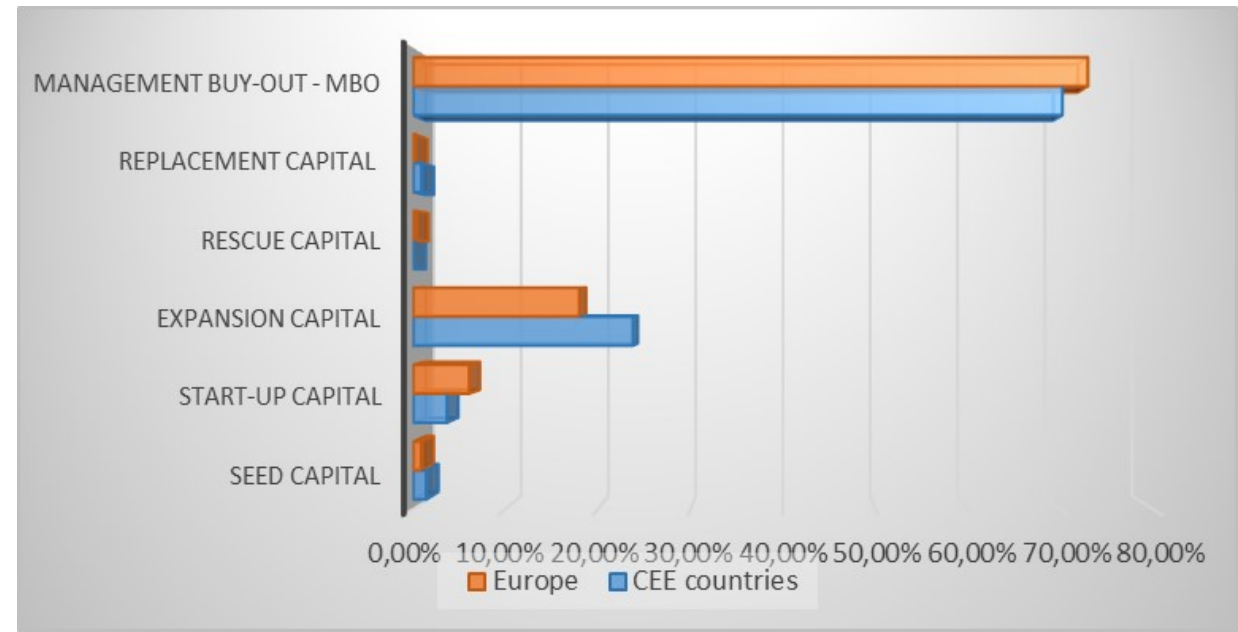

Fig. 1. Types of venture capital investments in CEE countries and in Europe in 2018

However, as regards the structure of the use of individual types of venture capital, this is approximately the same in both groups under review. Within individual types of venture capital, there is a clear prevalence of management buy-outs. MBO represents more than 70 $\%$ of its total volume of venture capital funding in CEE countries as well as in Europe as a whole. The second most commonly used type of venture capital is expansion capital (23.78\% share in Central and Eastern European countries, $17.97 \%$ share in Europe as a whole). 
In table 2 we can see the review of the volume of venture capital funding in Visegrad Group countries (Slovakia, Czech Republic, Poland and Hungary) in years 2010 - 2018.

Table 2. Venture capital investments in Visegrad Group countries (million EUR, years 2010 - 2018).

\begin{tabular}{|c|c|c|c|c|c|c|c|c|c|}
\hline Country/Year & $\mathbf{2 0 1 0}$ & $\mathbf{2 0 1 1}$ & $\mathbf{2 0 1 2}$ & $\mathbf{2 0 1 3}$ & $\mathbf{2 0 1 4}$ & $\mathbf{2 0 1 5}$ & $\mathbf{2 0 1 6}$ & $\mathbf{2 0 1 7}$ & $\mathbf{2 0 1 8}$ \\
\hline Czech Republic & 229 & 144 & 106 & 134 & 299 & 16 & 168 & 67 & 767 \\
\hline Poland & 653 & 678 & 473 & 380 & 251 & 896 & 805 & 2505 & 850 \\
\hline Hungary & 65 & 195 & 103 & 56 & 170 & 194 & 101 & 209 & 346 \\
\hline Slovakia & 15 & 9 & 98 & 2 & 12 & 17 & 17 & 4 & 26 \\
\hline Total V4 & $\mathbf{9 6 2}$ & $\mathbf{1 0 2 6}$ & $\mathbf{7 8 0}$ & $\mathbf{5 7 2}$ & $\mathbf{7 3 2}$ & $\mathbf{1 1 2 3}$ & $\mathbf{1 0 9 1}$ & $\mathbf{2 7 8 5}$ & $\mathbf{1 9 8 9}$ \\
\hline Total CEE & $\mathbf{1 3 3 6}$ & $\mathbf{1 2 4 7}$ & $\mathbf{1 0 0 5}$ & $\mathbf{7 8 9}$ & $\mathbf{1 3 1 1}$ & $\mathbf{1 7 0 0}$ & $\mathbf{1 7 0 3}$ & $\mathbf{3 5 3 2}$ & $\mathbf{2 6 8 5}$ \\
\hline $\begin{array}{c}\text { Visegrad Four's } \\
\text { percentage on a } \\
\text { total CEE countries }\end{array}$ & 72.01 & 82.28 & 77.61 & 72.50 & 55.84 & 66.06 & 64.06 & 78.85 & 74.08 \\
\hline
\end{tabular}

As can be seen from the table, the share of V4 countries in the total volume of venture capital used in Central and Eastern Europe varies from year to year. The lowest share can be seen in 2014 (55.84\%). On the contrary, we see the highest proportion in 2011. Up to $82.28 \%$ of the venture capital used in the countries of Central and Eastern Europe was in the Visegrad Group countries.

Development of risk capital in all countries during the period is considerably volatile. As we can see, the share of investment in V4 countries in the total volume of venture capital investments in CEE also fluctuates. In general, since 2010, the largest volume of venture capital within these countries has been used in Poland. In 2017, the volume of venture capital used in Poland was 2505 million EUR. Venture capital investments in Poland represent more than $89 \%$ of its total venture capital investments' s volume in CEE countries in this year. On the contrary, the lowest values were reported by Poland in 2014 (251 million EUR). The table shows that venture capital is least used in Slovakia. While in 2012 the volume of venture capital utilized in Slovakia was 98 million EUR, in the last reference year it was only 26 million EUR.

Although the ratio of Slovakia, Czech Republic, Hungary and Poland in the total volume of venture capital used in Central and Eastern Europe is relatively high, the level of utilization of capital, particularly in Slovakia and the Czech Republic is low. What are the main reasons that may cause this? Marková and Balcová [18] present two main types of barriers to the development of venture capital in Slovakia. These are barriers on the demand side and barriers on the supply side. Among the main obstacles on the supply side, the authors cite insufficient information about the possibilities of using venture capital as well as its weak promotion. On the supply side, the most important barrier was identified as the low innovation capacity of small and medium-sized enterprises. Due to the weak innovation potential, investors are not interested in financing projects of small and medium-sized enterprises, as they are not attractive enough for them. In the case of the Czech Republic, the Czech Republic has several assumptions that could positively support the use of venture capital - characterized by a relatively high education level of the population, a high number of small and medium-sized enterprises which undercapitalization is good prerequisites for venture capital use [10]. Despite the above assumptions for increasing the use of venture capital in the Czech Republic, this level is relatively low. Rajchlová et al. [13] ranks among 
the obstacles to the development of venture capital in the Czech Republic include inadequate support for start-ups and companies in the development phase in the area of tax benefits, no support for venture capital financing and insufficient knowledge and misunderstanding of this form of financing by entrepreneurs.

A comprehensive assessment of risk capital in individual European countries was developed by Groh et al. [3]. In The Venture Capital \& Private Equity Country Attractiveness Index, they assessed the attractiveness of countries for venture capitalists according to several criteria (economic activity, capital market level, taxation, investor / corporate governance, human and social environment and business culture and opportunities). The individual criteria examined are listed in Table 3.

Table 3. VCPE Country Attractiveness Index (V4)

\begin{tabular}{|l|c|c|c|c|c|c|c|c|}
\hline \multirow{2}{*}{ Country } & \multicolumn{2}{|c|}{ Slovakia } & \multicolumn{2}{c|}{ Czechia } & \multicolumn{2}{c|}{ Poland } & \multicolumn{2}{c|}{ Hungary } \\
\hline $\begin{array}{l}\text { VCPE Country } \\
\text { Attractiveness Index }\end{array}$ & $\mathbf{s c o r e}$ & rank & score & rank & score & rank & score & rank \\
\cline { 2 - 10 } & $\mathbf{5 0 , 5}$ & $\mathbf{7 1}$ & $\mathbf{6 5 , 7}$ & $\mathbf{3 3}$ & $\mathbf{7 2 , 4}$ & $\mathbf{2 6}$ & $\mathbf{5 7 , 7}$ & $\mathbf{5 2}$ \\
\hline Economic Activity & 73,7 & 65 & 85,4 & 28 & 89 & 19 & 81,3 & 43 \\
\hline Depth of Capital Market & 34,7 & 78 & 47,7 & 61 & 75,8 & 22 & 46,6 & 64 \\
\hline Taxation & 103,7 & 43 & 102 & 48 & 107,8 & 24 & 101,5 & 49 \\
\hline $\begin{array}{l}\text { Investor Protection and } \\
\text { Corporate Governance }\end{array}$ & 58,1 & 71 & 70,5 & 36 & 63 & 57 & 57,4 & 74 \\
\hline $\begin{array}{l}\text { Human and Social } \\
\text { Environment }\end{array}$ & 44,3 & 69 & 72,5 & 18 & 60,8 & 34 & 52,6 & 48 \\
\hline $\begin{array}{l}\text { Entrepreneurial } \\
\text { Opportunities }\end{array}$ & 58,6 & 46 & 72,9 & 26 & 66,8 & 34 & 59,9 & 45 \\
\hline
\end{tabular}

From the table above, then the graph we can assess which factors are barriers to the development of the venture capital market in the countries of the Visegrad Group and conversely, what are the advantages of the business environment of the country, which could attract investors. Only the main evaluation criteria are listed in the table below. 125 countries were evaluated in 2018. Among the monitored countries, Poland was the best (26th place), followed by the Czech Republic (33rd place), Hungary was in 52nd place and Slovakia was the last (71st place).

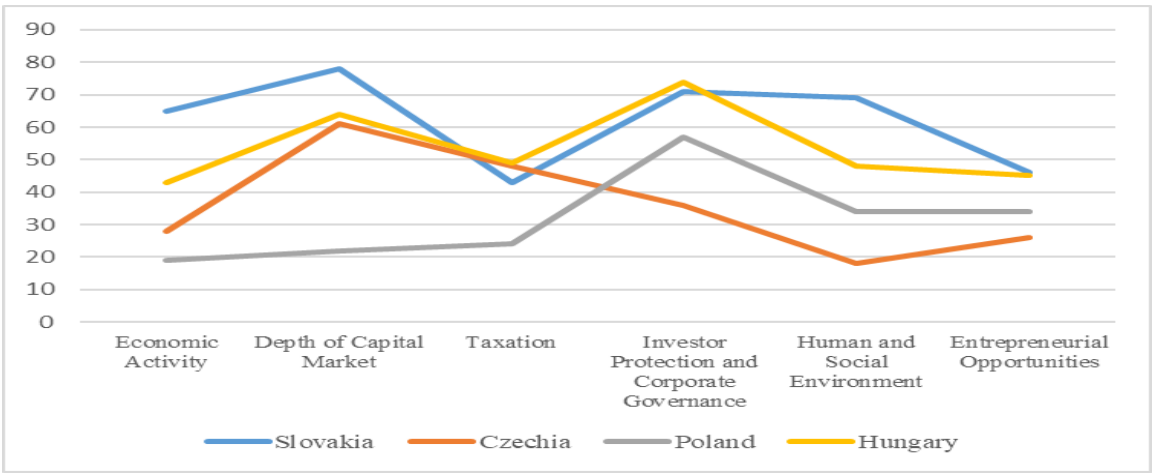

Fig. 2. Rank of Visegrad Group countries in 2018 
In the case of Poland, taxation and economic activity were rated the best. Compared to other countries, Poland also has a high rating in the case of the depth of capital market. On the contrary, the weaknesses of the Polish market could be the investor protection and corporate governance. The main barriers of Slovakia as the worst rated country among the V4 countries can be seen especially in the case of the depth of capital market - weak IPO activities in the market, low trading volume and the size of the stock exchange received a weak rating. The investor protection was also assessed negatively in the case of Slovakia the level of enforceability of the law is low, as well as the weak security of property rights. On the contrary, Slovakia managed to place better than the Czech Republic only in the criterion of taxation (43rd place, while the Czech Republic took 48th place). Entrepreneurial culture and the offer of opportunities were also evaluated relatively well in comparison with other factors. In the case of the Czech Republic, as the main barriers to the development of the use of risk capital, we can observe, as in the case of Slovakia, the level of the depth of capital market - the stock exchange is small, and the share of nonperforming loans in total loans is not low. On the contrary, in the case of the Czech Republic, the human and social environment as well as economic activity are evaluated positively. Hungary has a relatively good score in terms of economic activity and entrepreneurial opportunities. On the contrary, Hungary achieved a weak assessment in terms of investor protection and depth of capital market.

\section{Conclusion}

In this paper, we analyzed the use of venture capital in CEE countries. We came to some interesting findings. The most used forms of venture capital in CEE countries are management buyouts, which account for about $70 \%$ of total investment. Although there are rapid differences in the volume of venture capital utilization in CEE and other European countries, the structure of the various forms of investment is similar.

We also found that venture capital investment in the CEE countries represent only a small fraction of the investment of capital across Europe (3.33\%). The low level of use of risk capital is due to several factors that are interrelated. Authors Marková and Balcová [18]; Rajchlova et al. [13] consider the most important obstacles and barriers to venture capital development in particular:

- the low innovation capacity of SMEs, making them less attractive to venture capital investors,

- for some SMEs, their weaknesses are management and marketing skills,

- relatively low awareness among entrepreneurs about the possibilities of using venture capital,

- the tax and legal environment is not sufficiently supportive of the use of risk capital,

- the lack of legislative elements to promote the use of risk capital,

- underdeveloped capital markets (except Poland),

- poor support for R\&D,

- excessive bureaucracy (eg in the case of Poland, when starting a business, the registration period is approximately 3 times longer than in the average OECD country and at the same time it is more expensive: 4 times more expensive than the OECD average).

For the above reasons, despite the fact that in our opinion there is scope and relatively good conditions for the use of risk capital in the CEE region, the use of capital still on a low 
level. This implies that the State should take part in promoting venture capital support through various programs and raise awareness of this form of SME financing.

The presented working paper is the output of the scientific grants VEGA n. 1/0007/19 "Asset allocation in a low interest rate environment in the financial and non-financial companies in the Slovak republic".

\section{References}

1. A . P. Groh, H. Liechtenstein, International allocation determinants for institutional investments in venture capital and private equity limited partnerships. International Journal of Banking, Accounting and Finance, 3, 176-206 (2011)

2. A.P. Groh, H. Liechtenstein, Determinants for allocations to central eastern Europe venture capital and private quity limited partnerships. Venture Capital - An International Journal of Entrepreneurial Finance, 13, 175-194 (2010)

3. A.P. Groh, H. Liechtenstein, K. Lieser, M. Biesinger, The Venture Capital \& Private Equity Country Attractiveness Index. https://blog.iese.edu/vcpeindex

4. A.P. Groh, J. Wallmeroth, Determinants of venture capital investment in emerging markets. Emerging Martets Review, 29, 104-132 (2016)

5. A.Soloma, The importance of the depth of the capital market on international venture capital and private equity allocation decisions: The case of Poland. Economics and management, 18, 237-245 (2013)

6. C. Cabral-Cardoso, M. C. Cortez, L. Lopes, Venture capital and the financial crisis in Portugal: the VC managers' viewpoint. Journal of Small Business and Enterprise Development, 23, 1032-1056 (2016)

7. C. M. Mason, R. T. Harrison, Business angel investment activity in the financial Crisis : UK evidence and policy implications. SAGE Journal 33, 1 (2015)

8. E. Gomes Santana Félix, C. Pacheco Pires, M. A. Gulamhussen, The Determinanst of venture capital in Europe - Evidence across countries. Journal of Financial Services Research, 44, 259-279 (2013)

9. G. Prelipean, M. Boscoianu, M. Lupan, C. E. Nastase, Innovative financing solutions based on venture capital and private equity to support the development of enterpreneurship in Romania. Transformation in Business \& Economics, 13, 331-347 (2015)

10. H. Doláková, Rizikový kapitál a ČR - antonyma nebo homonyma? Ekonomika, financie a manažment podniku (Fakulta podnikového manažmentu EU, Bratislava, 2009)

11. J. Block, P. Sandner, Venture capital funding in the middle of the year 2011 : are we back to pre-crisis boom levels? Startegic Change: Briefings in Entrepreneurial Finance, 20, 161-169 (2011)

12. J. Block, P. Sandner, What is the effect of the financial crisis on venture capital financing? Empirical evidence from US Internet start-ups. Venture Capital - An International Journal of Entrepreneurial Finance, 11, 295-309 (2013)

13. J. Rajchlová, M. Baranyková, M. Polák, Z. Brož, Podmínky pro využití financování podniků formou private equity a venture kapitálu v České republice a vybraných evropských zemích - identifikace bariér, možnosti řešení. Trendy ekonomiky a managementu, 5, 33-43 (2011) 
14. J. Srpová, V. Řehoř, Základy podnikání. Teoretické poznatky, př́klady a zkušenosti českých podnikatelů (Praha, Grada Publishing, a.s., 2010)

15. L. Jeng, P. C. Wells, The determinants of venture capital funding : evidence across countries. Journal of Corporate Finance, 6, 241-289 (2000)

16. M. Kleinschmidt, Venture capital, corporate governance and firm value (Wiesbaden, GWV Fachverlage GmbH, 2007)

17. N. Bedu, M. Montalban, Analysing the uneven development of private equity in Europe: legal origins and diversity of capitalism. Socio-Economic Review, 12, 33-70 (2014)

18. V. Marková, P. Balcová, Odstránenie prekážok vo využívaní rizikového kapitálu slovenskými malými a strednými podnikmi. Ekonomika a spoločnost', 12, 67-75 (2011)

19. Y. Ning, W. Wang, B. Yu, The driving forces of venture capital investment. Small Business Economics, 44, 315-344 (2015) 